\title{
Tilbage til Abraham
}

\author{
En eksegetisk kommentar til Luther, Kant, Kierkegaard, \\ Nørager m.fl. ${ }^{1}$ \\ Lektor, ph.d. \\ Else K. Holt
}

\begin{abstract}
How can we understand the figure of Abraham in Genesis 22? Should he necessarily be understood as the ultimate example for the believer, Jewish, Christian (or Muslim)? And is Kierkegaard's radicalization of the exposition of Gen 22 in the New Testament Letter of James the only way of taking this text seriously? This article is an exegetical effort to understand the Aqedah as an indispensable narrative by and for a traumatized person (or people) who feels that his (or its) life is no more than "a test case" in the hands of God. Hereby, new aspects are added to the understanding of the narrative, which is seen as an expression of deep despair. Can a (historical-)critical reading of Gen 22 in the light of theories of trauma create space for a modern reconciliation with Kierkegaard's "Knight of Faith"? And do we not then need, after all, with Troels Nørager to "take leave of Abraham"?
\end{abstract}

Keywords: Gen 22 - Abraham - Kierkegaard - OT exegesis - trauma Persian period - exilic period - OT theology.

Første Mosebog 22, fortællingen om ofringen af Isak - eller rettere: fortællingen om, hvordan Abraham undgik at ofre sin søn Isak, den jødiske aqedah-fortælling - er en af de mest foruroligende fortællinger i Det Gamle Testamente. Den overfalder os, som den store gammeltestamentlige teolog Gerhard von Rad skriver, ${ }^{2}$ den går os direkte til hjertet i sin urimelighed; for de fleste af os er det ganske ligetil at identificere os med Abraham, der sættes på den ultimative prøve af Gud. Og det er for de fleste af os tilsvarende vanskeligt at forlige os med det billede af Gud, som tegnes i denne fortælling: en Gud, der leger med den troende, bare for at afprøve hans trofasthed, en Gud, der forlanger blind lydighed uden nogen forståelig grund; den Gud,

1. Denne artikel tilegnes mine studerende på GT1 gennem flere semestre. Uden denne undervisning og deres deltagelse i udforskningen af 1 Mos 22 ville artiklen ikke være blevet til.

2. Gerhard von Rad, Das Opfer des Abraham, Kaiser Traktate 6 (München: Chr. Kaiser Verlag 1971), 9. 
som ellers ofte beskrives som en "barmhjertig og nådig Gud, sen til vrede og rig på troskab og sandhed". ${ }^{3}$

\section{Abraham efter Det Gamle Testamente}

Aqedah-fortællingen har medført et utal af fortolkninger, som interessant nok ofte bevæger sig hurtigt fra det eksegetiske til det religionsfilosofisk-teologiske felt; ${ }^{4}$ i en dansk sammenhæng må Søren Kierkegaards udlægning i Frygt og Baven uden tvivl anses for at være den mest indflydelsesrige. 5 For Kierkegaard er Abraham "troens fader" og "troens ridder", den, der handler i absolut lydighed mod og tillid til Gud, og dermed suspenderer det etiske. Kierkegaards tolkning, på sin side, var ikke en eksegetisk udlægning af 1 Mos 22, men et teologisk-filosofisk opgør med Hegels religionsforståelse, hvorefter religionen underordnes filosofien, ja med hele oplysningstidens rationelle etiske religionskritik.

For oplysningstidens tænkere kan et guddommeligt bud aldrig retfærdiggøre en etisk forkert handling. Men hvad så, hvis Gud forlanger noget af os, som ikke i sig selv er retfærdigt og godt? I Der Streit der Fakultäten fra 1798 tager Immanuel Kant 1 Mos 22 som eksempel herpå. Han skriver:

Denn wenn Gott zum Menschen wirklich spräche, so kann dieser doch
niemals wissen, daß es Gott sei, der zu ihm spricht. Es ist schlechter-
dings unmöglich, daß der Mensch durch seine Sinne den Unendlichen
fassen, ihn von Sinnenwesen unterscheiden und ihn woran kennen
solle. - Daß es aber nicht Gott sein könne, dessen Stimme er zu hören
glaubt, davon kann er sich wohl in einigen Fällen überzeugen; denn

3. 2 Mos 34,4; Sl 86,15; Jonas 4,2 og mange andre steder i Det Gamle Testamente. 4. Der findes en righoldig litteratur om emnet, se eksempelvis Jon D. Levenson, "Abusing Abraham: Traditions, Religious Histories, and Modern Misinterpretations", Judaism 47 (1998), 259-77, jf. Levenson's tidligere monografi, The Death and Resurrection of the Beloved Son: The Transformation of Child Sacrifice in Judaism and Christianity (New Haven: Yale University Press 1993); se endvidere R. W. L. Moberly, The Bible, Theology, and Faith (Cambridge: Cambridge University Press, 2000); Troels Nørager, Taking Leave of Abraham: An Essay on Religion and Democracy (Aarhus: Aarhus University Press 2008); en instruktiv, kritisk oversigt findes hos John J. Collins, "Modern Theology", Reading Genesis: Ten Methods, red. Ronald Hendel (Cambridge: Cambridge University Press 2010), 196-214.

5. Henvisninger til Kierkegaard er i det følgende til Søren Kierkegaards skrifter 4, udgivet af Søren Kierkegaard Forskningscenteret (København: Gads forlag 2012), 97-210. 
wenn das, was ihm durch sie geboten wird, dem moralischen Gesetz zuwider ist, so mag die Erscheinung ihm noch so majestätisch und die ganze Natur überschreitend dünken: er muß sie doch für Täuschung halten.

\section{I en fodnote henviser Kant direkte til 1 Mos 22:}

Zum Beispiel kann die Mythe von dem Opfer dienen, das Abraham auf göttlichen Befehl durch Abschlachtung und Verbrennung seines einzigen Sohnes (das arme Kind trug unwissend noch das Holz hinzu) - bringen wollte. Abraham hätte auf diese vermeinte göttliche Stimme antworten müssen: "Daß ich meinen guten Sohn nicht tödten solle, ist ganz gewiß; daß aber du, der du mir erscheinst, Gott sei, davon bin ich nicht gewiß und kann es auch nicht werden", wenn sie auch vom (sichtbaren) Himmel herabschallte. ${ }^{6}$

Umiddelbart kan man jo synes, Kant har ret; kan en tilsynekomst, der kræver det ultimative offer, at man myrder sit eget barn, være Gud? Ikke desto mindre er det dét, Kierkegaard hævder, når han i Frygt og Baven taler om den teleologiske suspension af det etiske, om det sted, den situation, hvor den enkelte må sige nej til det almene og - i frygt og bæven - handle i tro, gøre det uforklarlige. ${ }^{7}$ Det er, hvad Kierkegaard kalder troens dobbeltbevægelse:

Abraham gjør nemlig, som tidligere tilstrækkelig udviklet, to Bevæ-
gelser. Han gjør Resignationens uendelige Bevægelse, og opgiver Isaak,
dette kan Ingen forstaae, fordi det er et privat Foretagende; men der-
næst gjør han i ethvert Moment Troens Bevægelse. Dette er hans Trøst.

6. Immanuel Kant, Der Streit der Fakultäten, Kants Werke VII, Akademie Textausgabe (Berlin: de Gruyter 1969), 63; se hertil videre Moberly 2000, 128-29; Levenson (1998), 260-62. Levenson anfører den, også i en nutidig dansk sammenhæng, interessante kritik af Kant, at når han sætter den rationelle teologi over den bibelske, så har det alvorlige implikationer for ethvert samfund, der gør det modsatte. Levenson peger på, at det vigtigste eksempel herpå på Kants tid var jødedommen, og hævder, at konsekvensen af Kants krav om en ren moralsk religion er die Euthanasie des Judenthums jf. (Kant (1969), 53(. Levenson skriver, (Levenson (1998), 262): "[Kant's] indictment of Abraham is thus more than an attack on one man's misjudgment: it is an indictment of Judaism itself and (though perhaps to a lesser degree) of Christianity as well. It is a call for the end of the religion of the commandments, the mitzvah, altogether-which he advocates in a phrase pointing to the worst excesses of our century, the 'euthanasia of Judaism,' the easy and painless death of the moral system that is based on Torah."

7. Jf. Kierkegaard (2012), 200-202. 
Han siger nemlig: dog vil det ikke skee, eller hvis det skeer, da vil Herren give mig en ny Isaak i Kraft nemlig af det Absurde (ibid., 203). ${ }^{8}$

Dette kan anses for at være den højeste grad af tro, og det er heri Kierkegaards virkeligt radikale forståelse af Abraham kommer til orde:

Hvis Abraham, da han stod paa Morija Bjerget, havde tvivlet, hvis han raadvild havde skuet omkring sig, hvis han, inden han drog Kniven, ved et Tilfælde havde opdaget Væderen, hvis Gud havde tilladt ham at offre den istedenfor Isaak - da var han dragen hjem, Alt var det Samme, han havde Sara, han beholdt Isaak, og dog hvor forandret! This hans Tilbagetog var en Flugt, han Fremtid maaskee Fortabelse. Da havde han hverken vidnet om sin Tro eller om Guds Naade... (ibid., 118).

Men det er samtidig en tro som Kierkegaard - gennem pseudonymet Johannes de silentio - tilstår, at han ikke har mod til, og som han i øvrigt heller ikke fremhæver som et eksempel til efterfølgelse:

... jeg kan beundre Abraham, jeg frygter ikke for, at Nogen ved denne Fortælling skulde fristes til letsindigen at ville være den Enkelte, men jeg tilstaar ogsaa, at jeg ikke har Mod dertil, og at jeg med Glæde renoncerer paa enhver Udsigt til at komme videre, dersom det blot var muligt, at jeg nogensinde, om end nok saa silde, kom saavidt (ibid., 209).

Måske er det her på sin plads at henvise til Luthers fortolkning af 1 Mos 22 i Genesisforelasningen fra 1539. Med sin præmoderne forudsætning, at Abraham forventede, at Isak skulle opstå fra de døde, som han i øvrigt formentlig deler med Kierkegaard, er Luther i sin forståelse meget langt fra at tale direkte til nutidens eksegese. For Luther er lydighed over for Gud eksemplarisk: "men der er én lydighed og én Helligånd" (WA 43, 224,42-225,1). ' Interessant i diskussionen med Kierkegaard er imidlertid Luthers understregning af, at vi ikke alle skal gøre det samme, og tror vi det, er vi fristet af Djævelen. Han skriver:

Vi forstår ikke disse ting [at Isak og Abraham lever, selvom de dør]. Alligevel må de overvejes, så vi kan forstå så meget som muligt. Jeg

8. Formentlig menes med "det absurde" troen på de dødes opstandelse, jf. nedenfor.

9. "Sed una est obedientia et unus spiritus sanctus" (oversættelse ved Sasja E. M. Stopa). 
indrømmer bestemt min sløvhed; mit asel bliver stående forneden og kan ikke bestige bjerget (WA 43, 220,11-13, min fremhævelse). ${ }^{10}$

\section{Og senere:}

Derfor skal Abrahams ekstraordinære eksempel ikke følges konsekvent. Men vi skal efterligne den lydighed og opstandelsestro, der har dræbt synd og død, sådan som det sker i ham og i hans søn. Lad derefter alle, på hver sit sted og i hver sin ordning, forblive i den samme tro og lad alle adlyde Gud. På den måde vil vi være englenes partnere, gæster og bordfæller i Guds rige (WA 43, 225,6-10). ${ }^{11}$

Går vi bag om Luthers udlægning til forståelsen af Abraham i Det Nye Testamente, er der to ting, der falder i øjnene. Den ene er, at når Kierkegaard omtaler Abraham som Troens Fader, gør han det $\mathrm{i}$ forlængelse af Paulus i Romerbrevet 4. Det er imidlertid ikke 1 Mos 22, der fører til denne ærestitel; Paulus tager her sit udgangspunkt i den tillid, som Abraham har til Guds løfte om at give ham en søn i 1 Mos 18 (Rom 4,18-22). I Romerbrevet er det derfor ikke den fortvivlede Abraham, men ham, der har modtaget et urimeligt godt og dog uforståeligt løfte, der tjener til eksempel. Den anden iøjefaldende ting ved forståelse af Abraham i Det Nye Testamente er, at Jakobsbrevet er helt utvetydigt i sit krav om radikal lydighed:

Nogen vil indvende: "Én har tro, en anden har gerninger." Vis mig da din tro uden gerninger, så skal jeg med mine gerninger vise dig min tro. Du tror, at Gud er én; det gør du ret i. Det tror de onde ånder også - og skælver. Tåbelige menneske, ønsker du bevis på, at tro uden gerninger er ufrugtbar? Blev vor fader Abraham ikke gjort retfærdig af gerninger, da han bragte sin søn Isak som offer på alteret? Som du ser, virkede troen sammen med hans gerninger, og det var af gerningerne, hans tro blev fuldkommen (Jak 2,18-22).

10. "Ista nos non assequimur, et tamen cogitanda sunt, ut assequamur, quantum possumus. Ego sane tarditatem meam agnosco, meus asinus infra resistit, nec potest ascendere in montem". Jeg takker Post-doc, PhD Sasja E.M. Stopa for at gøre opmærksom på netop dette aspekt ved Luthers tekst.

11. "Itaque exemplum illud singulare Abrahae non est trahendum in consequentiam. Sed obedientiam et fidem resurrectionis, occisi peccati, mortis, quae in ipso et filio fiunt, imitari debemus. Postea quisque suo loco et ordine in eadem fide maneat, et obediat Deo. Ita erimus socii Angelorum, hospites et convivae regni Dei”. Luther advarer i øvrigt i denne forbindelse stærkt mod at lade sig overbevise af engle. Der er slet ikke brug for dem, efter at Gud har åbenbaret sig for menneskene i Kristus, ja Luther har endda den vane dagligt at bede Gud undlade at sende engle til ham af nogen som helst grund (ibid., 126). 
Så altså: Er Abraham et eksempel til efterfølgelse, eller er han ikke? I Jakobsbrevet er der ingen tvivl; tro uden gerninger er "ufrugtbar" og "det var af gerningerne, hans tro blev fuldkommen." Tydeligere kan det ikke siges, og Abraham tjener ubetvivleligt til eksempel for den forfulgte i den tidlige kristendom. For Luther på den anden side er der heller ingen tvivl. Abraham og Isak er udelukkende eksempler ved deres tro på de dødes opstandelse, fordi de begge tror, at Gud ikke alene kan, men helt sikkert vil, oprejse de døde. ${ }^{12}$ For mig at se er Kierkegaard mere tvetydig; Abraham er på den ene side det radikale eksempel på den individuelle tro, og hvem vil ikke gerne ligne troens ridder? I sin Lovtale over Abraham spørger Kierkegaard inkvisitoriskopfordrende sin læser: "Vi læse i hine hellige Skrifter: 'og Gud fristede Abraham, og sagde: Abraham, Abraham hvor er Du? men Abraham svarede: her er jeg.' Du til hvem min Tale henvender sig, var det saaledes Tilfælde med Dig?”' (Kierkegaard 2012, 117). På den anden side er han et ganske uopnåeligt forbillede for Kierkegaard. Med Troels Nøragers ord er det "comprehensible that Kierkegaard chose Genesis 22 to argue his case against Hegel that faith is a paradox which cannot be mediated" (Nørager 2008, 95, Nøragers fremhævelse). ${ }^{13}$

For Nørager selv, hvis hovedinteresse er forholdet mellem religion og demokrati, er Kierkegaards Abraham derimod ikke noget legitimt eksempel i vores egen tid:

Provided that the goal of our interpretive effort is not just a re-telling or paraphrase of F\&T [sc. Fear and Trembling] but a productive re-reading relevant to the problems of our time, I see no alternative to taking leave of Abraham. From him we can learn nothing. If anything he is an early warning of the contemporary dangers of absolute faith and listening to the alleged voice of a 'strong' and commanding God (Nørager 2008, 97, Nøragers fremhævelse. $)^{14}$

12. Ibid., 119. Således også henvisningen til Abraham i Hebræerbrevet 11,17-19: "I tro bragte Abraham Isak som offer, da han blev sat på prøve, og var rede til at ofre sin eneste søn, skønt han havde fäet løfterne, og der var blevet sagt til ham: 'Det er efter Isak, dine efterkommere skal have navn;' for han regnede med, at Gud havde magt endog til at oprejse fra de døde, og derfra fik han ham også billedligt tilbage”. Kierkegaards bemærkning om, at Herren vil give Abraham en ny Isaak i Kraft af det Absurde kan formentlig forstås på samme måde (se ovenfor).

13. For en nøjere gennemgang og diskussion af Kierkegaards fascinerende og radikale læsning af 1 Mos 22 henviser jeg i øvrigt til Nørager 2008, kapitel 2 og 7.

14. Tilsvarende Levenson, der argumenterer fra en jødisk, bibelsk-teologisk synsvinkel, Levenson 1998, 273: “...historically, Jews, Christians, and Muslims have approached their duties in the light of a deposit of revelation established in a canon of scripture and (usually) authoritative tradition ... To ask whether Abraham should have heeded the voice that addresses him in Gen 22:2 generates an interesting and stimulating thought-experiment, to be sure. A positive answer, however, 


\section{Første Mosebog 22 i historisk-kritisk belysning}

Betyder Nøragers analyse af Kierkegaard nu, at vi også må "take leave of Abraham" i hans gammeltestamentlige, teologiske sammenhæng? Er der ikke et alternativ til Kierkegaards radikale forståelse? Det er, hvad jeg vil undersøge i det følgende. Det er allerede sket i forskningen et utal af gange. Men ofte synes tolkningerne, forståeligt nok, at have mere eller noget andet på spil end fortællingen selv. Forståeligt, fordi fortællingen, som jeg skrev indledningsvis, i bund og grund er urimelig, uforståelig, ikke til at komme overens med, og dog samtidig helt uundgåelig. Vi kan ikke bare lægge den til side som irrelevant den trænger sig på i sin almene gru. Eller som en præst engang sagde til sine konfirmander: "Hvad nu, hvis Isak lå på kræftafdelingen på Kommunehospitalet?"

Men skal vi forstå fortællingen på dens egne betingelser, må vi undersøge hvilket teologisk miljø, den er nedskrevet i. Hvilke livsbetingelser taler den ind i, hvad er dens klangbund? Tillad mig at gå en lille omvej.

\section{Israel i Persertiden - den religiøse enklave}

De senere år har interessen hos en del gammeltestamentlige forskere i stigende grad samlet sig om persertiden, det vil sige tiden fra persernes sejr over babylonerne i 539 f.kr. og frem til perserkongen Dareios III's død i 330 f.Kr., som historisk baggrund for samlingen og skriftliggørelsen af dele af Det Gamle Testamente. ${ }^{15} \mathrm{Og}$ ser vi på udviklingen af den tidlige jerusalemitiske jødedom i denne periode, giver den god mening som intellektuel baggrund for en fortælling om Abraham som en troens og lydighedens helt. Med en bestemmelse hentet fra den amerikanske antropolog Mary Douglas kan dette miljø nemlig beskrives som en religiøs enklave, det vil sige en menighed - den tyske gammeltestamentler Erhard Gerstenberger taler

does not in any way imply that a contemporary Jew, Christian, or Muslim should do likewise (as even Kierkegaard recognized)".

15. Se hertil fx Reinhard Gregor Kratz, Historisches und biblisches Israel. Drei überblicke zum Alten Testament (Tübingen: Mohr-Siebeck 2013); engelsk oversættelse: Historical and Biblical Israel: The History, Tradition, and Archives of Israel and Judah, oversat af Paul Michael Kurtz (Oxford: Oxford University Press 2015); Erhard S. Gerstenberger, Israel in der Perserzeit: 5. und 4. Jahrhundert v. Chr., Biblische Enzyklopädie (Stuttgart: Kohlhammer Verlag 2005); engelsk oversættelse: Israel in the Persian Period: The Fifth and Fourth Centuries B.C.E. oversat af Siegfried S. Schatzmann (Atlanta: Society of Biblical Literature 2011). 
om eine Glaubensgemeinschaft ${ }^{16}$ - hvori ortodoksi og ortopraksi er af afgørende betydning. ${ }^{17}$ Sådanne samfund er præget af nødvendigheden af en ledelse, der kan bevare sin autoritet, fordi den af medlemmerne af enklaven anerkendes som pletfri. Modsætningen hertil er en hierarkisk samfundsopbygning, hvor medlemmerne af samfundet har deres plads via en fast orden, baseret på slægt og tradition, og som derfor i udgangspunktet er meget stabil. ${ }^{18}$ Men i den sammenhæng, hvor ledelsesstrukturen principielt er flad, og hvor lederen ikke er en "født", men en meriteret leder, kan kun en pletfri person - i gammeltestamentlig sprogbrug "den retfærdige" - lede enklaven og forhindre, at medlemmerne falder ved siden af "vejen". Netop vejen er et billede, der gang på gang i Det Gamle Testamente på tværs af teologiske forskelligheder betegner den frommes rette liv med Gud. I enklavemenigheden gælder det om at holde medlemmerne på vejen, så de ikke falder fra og må fjernes fra menigheden. ${ }^{19}$ Derfor er belæring, også af ungdommen, af afgørende betydning, og den fromme retfærdige må hele tiden bekymre sig om sin egen vej.

Vi møder ham i Sl 1:

Lykkelig den, som ikke vandrer

efter ugudeliges råd,

som ikke opholder sig på synderes vej

og ikke sidder blandt spottere,

men har sin glæde ved Herrens belæring ${ }^{20}$

og grunder på hans belæring dag og nat.

16. Erhard S. Gerstenberger, Theologien im Alten Testament: Pluralität und Synkretismus alttestamentlichen Gottesglaubens (Berlin: Kohlhammer Verlag 2001), engelsk oversættelse: Theologies in the Old Testament, oversat af John Bowden (Minneapolis: Fortress press, 2002), 166-216, jf. også Gerstenberger 2005.

17. Mary Douglas, In the Wilderness: the Doctrine of Defilement in the Book of Numbers (Oxford: Oxford University Press 2001). Heri især kapitel 2: "The Politics of Enclaves", side 42-62. Et moderne, illustrativt eksempel er Amish-samfundene i Nordamerika og Canada, religiøse minoritetssamfund i et omgivende majoritetssamfund, der bevidst holder deres egne enklaver rene for "vranglære" og adfærd, der strider mod den religiøse lære, ved aktivt, så vidt muligt, at vende ryggen til omgivelserne. For en dansk introduktion til Douglas' teori, se Hans J. Lundager Jensen, "Neh 8,1-12: Med et tillæg om Mary Douglas' definition af enklave-kultur" (s. 8-13). http://pure.au.dk/portal/files/89892787/Neh_8_2014_10_10_med_ Douglas_G_G.pdf

18. Jf. Douglas 2001, kapitel 3: "A Priestly Hierarchy", side 63-82.

19. Jf. den såkaldte "shunning" af heterodokse og heteropraktiske medlemmer af Amish-grupper eller ultraortodokse, fx hasidiske, jødiske menigheder.

20. . תוֹ (tôrăh), der ofte oversættes med "lov," således også i DO92. 
Han er som et træ,

der er plantet ved bækken;

det bærer frugt til rette tid,

og dets blade visner ikke.

Alt, hvad han gør, lykkes for ham. ${ }^{21}$

Den rette lære for persertidens (og de følgende århundreders) torafromme jerusalemit er den, som vi finder i den positive visdom, nemlig at Gud sørger for, at der er op og ned på tilværelsen, så det går de retfærdige (צִ șaddiqîm) godt, mens deres modsætning, de ugu-

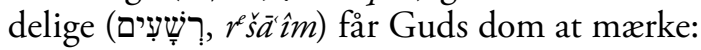

Sådan går det ikke de ugudelige;

de er som avner,

der blæses bort af vinden.

Derfor står de ugudelige ikke fast ved dommen,

syndere ikke i retfærdiges forsamling.

Herren kender de retfærdiges vej,

men de ugudeliges vej går til grunde

(Sl 1,4-6).

Denne beskrivelse er naturligvis ikke dækkende. Med til belæringen i enklaven hører også begivenheder fra Israels historie, der skal demonstrere, dels hvor god Gud har været mod sit folk, dels hvor galt det kan gå, hvis folket forlader vejen. Gode eksempler herpå finder vi i de såkaldt historiske salmer, Sl 78; 105-106, der gennemgår specielt ørkenvandringsfortællingerne med særligt henblik på parænese. Sl 105 har især fokus på Guds velgerninger, mens Sl 106 understreger og bekender folkets syndighed. S1 78 samler indtrykket:

Mit folk, hør på min belæring,

vend jeres øre mod min munds ord.

Jeg vil åbne min mund med billedtale,

jeg vil fremføre gådetale fra fortiden.

Det, vi har hørt og erfaret,

det, vore fædre har fortalt os,

skjuler vi ikke for deres børn;

vi fortæller den kommende slægt

om Herrens glorværdige gerninger og styrke,

om de undere, han har gjort.

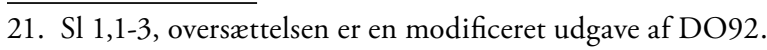


[...

De holdt ikke Guds pagt

og ville ikke følge hans lov.

De glemte hans gerninger

og de undere, han havde vist dem.

(S1 78,1-4.10-11)

Som det fremgår, er der i enklaven fokus både på kollektivets og på den enkeltes ortodoksi, det vil sige syndighed og retfærdighed. Derfor finder vi i persertiden de kollektive bodsbønner, hvor en leder på menighedens vegne bekender folkets historiske og aktuelle synder og beder Gud om tilgivelse og hjælp i en nødsituation; et klassisk eksempel herpå er Nehemias 10. Dertil kommer også individuelle bodsbønner som Sl 51.22

Det er ind i denne enklavistiske sammenhæng, vi skal forstå Abraham-skikkelsen i 1 Mos 22. ${ }^{23}$

\section{Abraham, den retfærdige}

Vi kender fortællingen. Efter Isaks fødsel og Ismaels uddrivelse fra hjemmet sætter Gud Abraham på prøve: han skal drage afsted sammen med drengen til et ukendt sted, hvor han skal ofre ham. Abraham gør, som Gud befaler, men bliver i sidste øjeblik af en engel forhindret $\mathrm{i}$ at slagte sin søn, for, som englen siger: "Nu ved jeg, at du frygter Gud og end ikke vil nægte mig din eneste søn”. Abraham får øje på et passende offerdyr, en vædder, som han ofrer i stedet for sønnen, og han navngiver bjerget "Jahve ser". Derefter genoptager englen sin tale på Guds vegne, idet han gentager den tidligere velsignelse, der lover Abraham et talrigt, magtfuldt afkom, "fordi du adlød mig".

1 Mos 22,1 siger ganske klart, hvad det er, teksten går ud på: Gud sætter Abraham på prøve. ${ }^{24}$ Teksten tolker således sig selv, og der er ingen vej uden om denne forståelse; den Gud, vi møder i 1 Mos 22 er

22. Om den tidlige jødiske menighed i Jerusalem som enklavemenighed og forbindelsen til spørgsmålet om aksetiden, dens religionsform(er) og undervisning, se videre Line Søgaard Christensen, Instructing the Israelites: Axiality, teaching, and rituals in the Hebrew Bible (Aarhus Universitet: upubliceret ph.d.-afhandling 2016). 23. Om andre Abraham-tekster i lyset af Douglas, se endvidere Hans J. Lundager Jensen, "Den patriarkalske Abraham", Dansk Teologisk Tidsskrift 78 (2015), 320340.

24. Således fx også Claus Westermann, Genesis 12-36. Biblischer Kommentar Altes Testament 1/2 (Neukirchen: Neukirchener Verlag 1981), 434. 
en gud, der afprøver sine tilhængeres trofasthed. Jahve er en gud, der ser, og - føjes det til i v. 14 - Jahve er en gud, der viser sig og griber ind i det enkelte menneskes liv. Den tilhænger, der adlyder den guddommelige befaling uden at tøve, bliver til gengæld rigt belønnet. Der er ingen vej uden om en sådan Gud. Abraham kan ikke unddrage sig Guds befaling, hvis han vil regnes blandt de gudfrygtige. Han overvejer ikke et sekund at undslå sig. Han forhandler ikke med Gud om det rimelige i hans forlangende. Abraham i 1 Mos 22 er helt forskellig fra den Abraham, vi møder i 1 Mos 17, hvor han åbenlyst betvivler og vantro ler ad Guds løfter om Isaks fødsel, til trods for at Gud netop har indgået en pagt med ham, og også fra fremstillingen i 1 Mos 18, hvor latteren ganske vist er overladt til Sara (vers 10-16), men hvor Abraham til gengæld indgår i en ganske elegant tuskhandel med Gud om prisen for at redde Sodoma fra udslettelse (1 Mos 18,1633). ${ }^{25}$ Abrahams trumf i den forbindelse er Guds retfærdighed: "Vil du virkelig udrydde retfærdige sammen med uretfærdige?" spørger Abraham Gud, da han har sat ham ind i sine planer for Sodoma.

Måske er der halvtreds retfærdige i byen. Vil du så virkelig udrydde dem og ikke tilgive stedet på grund af de halvtreds retfærdige, som er i den? Du kan umuligt handle sådan og slå retfærdige ihjel sammen med uretfærdige, så retfærdige og uretfærdige får samme skæbne. Det kan du umuligt! Skulle han, der dømmer hele jorden, ikke øve ret? (1 Mos $18,23-25)$.

De retfærdiges og de uretfærdiges skæbne og Guds egen retfærdighed er temaet for denne indledning til fortællingen i 1 Mos 19, der uimodsigeligt viser, at der ikke er én eneste retfærdig i Sodoma, ${ }^{26}$ og at Guds udslettelse af byen derfor er helt retfærdig. Det er denne retfærdige Gud, der sætter Abraham på prøve.

Men også Abrahams egen retfærdighed tematiseres i den umiddelbare kontekst til 1 Mos 22, nemlig i fortællingen i 1 Mos 21,22-34, der omhandler en pagtslutning mellem Abraham og filisterkongen Abimelek. Her bliver Abrahams tilforladelighed understreget, selv blandt fremmede, som ikke altid er til at stole på, og Guds trofasthed mod Abraham fremhæves fra fortællingens begyndelse, hvor det hedder:

25. Se til bl.a. denne fremstilling af Abraham Hans J. Lundager Jensen, "Abraham, høflighedens ridder," Dansk Teologisk Tidsskrift 74 (2011), 3-21.

26. For en diskussion af 1 Mos 19 fra en nutidig teologisk synsvinkel se Ronald Hendel, Chana Kronfeld \& Ilana Pardes i Hendel 2010, 71-91; Danna Nolan Fewell \& David M. Gunn, Gender, Power, and Promise: The Subject of the Bible's First Story (Nashville: Abingdon Press 1993), kap. 3: "Assault at Sodoma”, side 56-67. 
På den tid sagde Abimelek og hans hærfører Pikol til Abraham: "Gud er med dig i alt, hvad du foretager dig. Sværg nu her på stedet ved Gud, at du aldrig vil bedrage mig eller min slægt og mine efterkommere. Den troskab, jeg har vist dig, skal du vise mig og det land, hvor du bor som fremmed”. Abraham svarede, at han ville sværge (1 Mos 21,22-24).

I sin kortfattethed er 1 Mos 22,1 altså ganske klar. Fortolkere, både kristne og jødiske, har, provokeret af denne kortfattethed, diskuteret Abrahams tavshed i de følgende vers som udtryk for hans indre kamp ${ }^{27}$ eller understreget hans faste tro på, at Gud under alle omstændigheder ville gribe ind og frelse den udvalgte søn, som skulle føre slægten og dermed folket videre. ${ }^{28}$ Men ingen af disse forsøg på at neddæmpe fortællingens pointe, at Gud fordrer ubetinget lydighed af Abraham som forudsætning for at løftet om velsignelse skal gå i opførelse, har rod i fortællingen. De to temaer, kamp og tro, findes overhovedet ikke i 1 Mos 22. Gud er en gud, der prøver sin tjener.

Til gengæld er der heller ingen grund til at afvise, at det er en reel prøvelse, Abraham udsættes for. En nærlæsning af teksten viser det med underspillet tydelighed. I v. 1b-2 udspiller der sig en samtale mellem Gud og Abraham, hvor Gud kalder: "Abraham" og Abra-

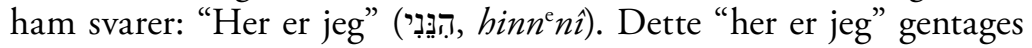
i 22,7.11, hver gang som en opmærksomhedsskabende markør af en parathed til at lytte og respondere. Hinn n $n \hat{\imath}$ som en sådan markør finder vi i Det Gamle Testamente i en række fortællinger, hvor Gud kalder på et menneske, der skal gøre en særlig indsats: Foruden Abraham (1 Mos 22,1.7.11) er det Jakob (1 Mos 31,11; 37,13; 46,2), Moses ved den brændende tornebusk (Ex 3,4), Samuel som barn (1 Sam 3) og ikke mindst profeten Esajas ved hans kaldelse i Es 6. ${ }^{29}$ To steder i sene dele af Esajas' bog er det modsat Gud, der siger "her er jeg" til det folk, der kalder på ham (Es 58,9; 65,1).

Abraham viser sig altså fra første færd parat til at lytte, og da Gud giver sin befaling om at ofre Isak, er teksten så kortfattet, at han end ikke svarer. Vers 3 fortæller bare lakonisk, at "tidligt næste morgen sadlede Abraham sit æsel og tog sine to karle og sin søn Isak med. Da

27. Således især Kierkegaard, se "Stemning” (Kierkegaard 2012, 109) og "Problema III" (ibid. 200-07).

28. Et tema, der som nævnt så at sige videreføres i kristne udlægninger som Hebræerbrevets, Luthers og Kierkegaards, der understreger Abrahams tro på, at Isak skal genopstå fra de døde.

29. Herudover anvendes formen også formelt mellem mennesker, fx i fortællingen om Isaks velsignelse af Jakob, men ikke Esau (1 Mos 27), men også mere uformelt, se 1 Mos 37,13; 1 Sam 22,12; 2 Sam 1,7. 
han havde kløvet offerbrændet, begav han sig på vej til det sted, Gud havde givet ham besked om".

Og dog er der plads til emotioner allerede i denne korte samtale, for Gud giver ikke alene befaling til at ofre Isak, men teksten understreger ganske tydeligt Isaks relation til sin far. I en staccato ophobning af relationelle betegnelser siger Gud: "Tag din søn, din eneste, som $d u$ elsker, Isak, og gå...” Prøvens grusomhed er tilstede i de personlige pronominer. Denne nærhed mellem far og søn fortsætter i den senere samtale mellem de to på vej op ad bjerget. De to tjenestedrenge er ladt tilbage ved bjergets fod sammen med æslet, mens Abraham og Isak alene fortsætter mod målet. Abraham fordeler offerudstyret imellem dem: "Abraham tog offerbrændet og lagde det på sin søn Isak. Selv tog han ilden og kniven, og så gik de to sammen" (v. 6). Man bemærker, hvordan fællesskabet imellem dem understreges af de afsluttende ord: "og så gik de to sammen". Undervejs siger Isak:

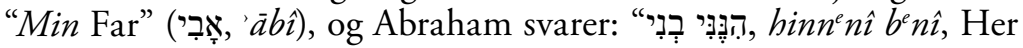
er jeg, min dreng”, og på Isaks spørgsmål: "Vi har ilden og brændet, men hvor er offerlammet?" svarer Abraham: "Gud vil selv udse sig et offerlam, min dreng". Igen fremhæver de personlige pronominer den tætte relation mellem de to, og endnu engang fortælles det, at "så gik de to sammen."

Ind i den nøgterne fortælling udfoldes således det emotionelle drama, men ganske stilfærdigt. Hverken Abrahams eller Isaks følelser beskrives direkte; deres nære relation fremhæves blot af den sproglige form. På det overordnede plan handler fortællingen om endnu en trussel mod løftet til Abraham om at blive til en stor familie, en trussel, der afværges af Guds indgriben; ${ }^{30}$ men ind i denne overordnede fortælling er lagt det lag af forbundenhed mellem far og søn, som gør fortællingen nærværende. Man behøver ikke overveje forskellene mellem familiestrukturer i datiden og vores egen tid. Selv med disse forskelle er der lighedspunkter, der kalder på en umiddelbar forståelse hos tilhøreren.

Abrahams lydighed så vel som det befalede offers grusomhed understreges også i det følgende afsnit, vers 9-10. Atter er det den sproglige form, der viser det. Omhyggeligt og pertentligt fortælles det, hvordan Abraham bygger et alter, lægger brændet til rette på det, binder sin søn Isak og lægger ham oven på brændet, sådan som et

30. I 1 Mos 12,10-20 fortælles det, at Abram og Saraj pga. hungersnød må forlade Kana'an, som de netop har taget i besiddelse (1 Mos 12,4-9), og rejse til Egypten, og at Saraj bliver taget ind i faraos harem, men at de to, ved Guds indgriben, senere kan forlade Egypten med stor rigdom. Denne fortælling repeteres i kap. 20, det vil sige kort før 1 Mos 22, således at "løftet i fare” må betragtes som et gennemgående tema i Abrahams fortælling. 
rigtigt brændoffer skal forberedes. Derpå rækker han hånden ud og tager kniven for at slagte sin søn. ${ }^{31}$ På dette højdepunkt i den narrative spændingsbue kalder Jahves engel: "Abraham, Abraham", og igen svarer han "התוּנִּנ, Her er jeg" (v. 11). Nu har Abraham vist, at han er gudfrygtig og lydig, “... og end ikke vil nægte mig din eneste søn” (v. 12). Hvem den talende er søger teksten at sløre, her som i den senere velsignelse. Egentlig er det jo Jahves engel fra himlen, ${ }^{32}$ men af indholdet, især slutningen af v. 12, fremgår det, at det er Gud. ${ }^{33}$ Denne sløring fortsætter i den afsluttende tale i v. 15-18, hvor det formelt set er Jahves engel, der taler, men hvor det indlagte "siger Jahve" viser, at englen her fungerer som en himmelsk profet. ${ }^{34}$ Det er altså Jahve selv, der udtaler fortællingens pointe, at fordi Abraham har adlydt Gud og handlet som han gjorde og ikke ville nægte Gud selv det mest dyrebare han har, sin søn og slægtens viderefører, så vil Jahve gøre ham til et stort og mægtigt folk (v. 15-18). Her genoptages og udvides velsignelsen fra 1 Mos 13,16 og 15,5, at Abrahams efterkommere skal blive "så talrige som himlens stjerner og som sandet ved havets bred", og et nyt løfte tilføjes, nemlig at "dine efterkommere skal erobre deres fjenders porte”. Dette fokus på magt er ellers temmelig fraværende i fremstillingen af den Abraham, som med rette er blevet kaldt "høflighedens ridder" (se ovenfor); men her optræder det i øvrigt sene billede af ham som en mægtig krigsherre, som ellers kun kendes fra 1 Mos 14,1-16.

Igennem denne fortælling bliver den absolut lydige Abraham et perfekt forbillede for persertidens og de følgende århundreders jødiske ortodokse menigheder, der samlede sig om én og kun én Gud, Jahve. Den teologi, der var blevet grundlagt blandt de hjemvendte jerusalemitter i persertiden er jo den, der videreføres i Makkabæertiden, hvor zelotisk rettro fører til oprør mod de fremmede magthavere netop på grund af religiøse uoverensstemmelser (se 1 Makk 1,41-64), og hvor især Anden Makkabæerbogs tekster vidner om en begejstring for martyriet, som langt overskrider Abrahams tavse lydighed (se 2 Makk 6,18-7,42). ${ }^{35}$

31. Verbet שח, šăhat, anvendes i Anden og Tredje Mosebog om slagtning af offerdyr.

32. Altså et væsen, der med sin himmelbundethed adskiller sig fra de guddommelige udsendinge, der ellers optræder i Abrahamfortællingen, fx 18,16-19,28, hvor de dels beskrives som "mænd" dels som "engle".

33. En sådan sløring af en alt for antropomorf Gud finder vi også i fortællingen om Jakobs kamp ved Penu'el, 1 Mos 32,23-30: “En mand” giver sig i kamp med Jakob. 34. "Siger Jahve" er en oversættelse af en formel, overtaget fra profetskrifterne,

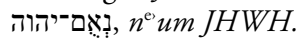

35. Jeg diskuterer ikke her historiciteten af de i 1.-2. Makkabæerbog gengivne fortællinger; min pointe er rent litterær, nemlig at martyrfortællinger afspejler en bestemt stemning blandt de "troende." Som introduktion til Makkabæerbøgerne og 
Derimod kan man ikke nødvendigvis hævde, at kravet til Abraham om at ofre sin søn gælder alle rettroende. Det er netop som familiens og folkets grundlægger, Abraham bliver sat på prøve, ikke som en almindelig israelit. Det fremgår af velsignelsen, og det fremgår af konteksten, som drøftet ovenfor. Abraham er den velsignede, som Gud har indgået en pagt med og givet store løfter, og netop den udvalgte velsignede er ham, der sættes på prøve. På denne måde bliver Abrahams absolutte lydighed måske en slags målestok for den ideelle leders oprigtighed og kan virke som inspiration til den, der søger retfærdighed. Men det er ikke enhver, der bliver beordret at ofre sin egen fremtid.

\section{Abraham, Isaks far}

Klagesangene i Det Gamle Testamente udtrykker en teologi og en menneskelig henvendelse til Gud, der er ganske anderledes end den, som kommer til udtryk i den ovenfor udviklede forståelse af 1 Mos 22. Ikke desto mindre danner netop disse digte $\mathrm{i}$ al deres fortvivlelse en idémæssig og emotionel klangbund for den tidlige eksiltids forståelse af aqedah-fortællingen, altså tiden forud for persertiden.

Klagesangene er fem digte, der med stor sandsynlighed stammer fra de første årtier efter Jerusalems og templets fald i 587 f.Kr. De er blevet betegnet som overlevelseslitteratur ("literature of survival"), ${ }^{36}$ det vil sige litteratur, der er skrevet i efterdønningerne af en katastrofe og beskriver, hvordan man overlever den; men også litteratur, der gennem sit efterliv overlever sin egen tid og oprindelige katastrofe og taler ind i sin eftertid ved at generere andre tekster, sådan som netop Klagesangene har gjort det.

Hovedstemmen i Klagesangene tilhører en anonym kvinde, der somme tider er Zion selv, somme tider Jerusalems krigsramte kvin-

deres tid, se Shaye J.D. Cohen, From the Maccabees to the Mishnah. Third Edition (Louisville: Westminster John Knox Press 2014), 19-52.

36. Se Tod Linafelt, Surviving Lamentations: Catastrophe, Lament, and Protest in the Afterlife of a Biblical Book (Chicago: Chicago University Press 2000); jf. Kathleen M. O'Connor, Lamentations and the Tears of the World (Maryknoll: Orbis Books 2003); Elizabeth C. Boase, "The Traumatised Body: Communal Trauma and Somatisation in Lamentations", Trauma and Traumatization in Individual and Collective Dimensions: Insights from Biblical Studies and Beyond, red. Eve-Marie Becker m.fl. SANt2 (Göttingen: Vandenhoeck and Ruprecht 2014), 193-209; en dansk introduktion findes i Mette Stegelman, "Hvem er hvem i Klagesangene?", Dansk Teologisk Tidsskrift 76 (2013), 242-260. 
der, der, til trods for erkendelse af selv at være synder, klager over den guddommelige strafs urimelige voldsomhed:

Den spædes tunge klæber til ganen af tørst;

børn tigger om brød, ingen rækker dem det.

De, der før spiste lækkerier, ligger forkomne på gaderne;

de, der blev båret i purpur, trykker sig nu i skarnet.

Mit folks datters skyld var større end Sodomas synd,

den by, der blev ødelagt på et øjeblik, uden at nogen løftede en hånd.

Hendes fyrster var renere end sne, hvidere end mælk,

rødere end selv koraller, deres skikkelse var safir;

nu er de sortere end sod, man genkender dem ikke på gaden.

Deres hud klæber til knoglerne, den er tør som træ.

De, der blev dræbt af sværdet, er lykkeligere end de, der dræbes af

sulten,

mens de ligger sårede hen, fjernt fra markens afgrøde.

Med egne hænder må mødre nu koge deres børn;

det er blevet deres føde, for mit folks datter er lemlæstet.

Herren har givet sin vrede frit løb...

(Klages 4,4-11)

Sproget i Klagesangene er, som den talende, ganske vist metaforisk, men med en stærk forankring i en levet virkelighed, hvor mødre måtte se deres børn dø af sult. Står beskrivelsen i Anden Kongebog og Jeremiasbogen til troende, belejrede babylonerne Jerusalem i knapt tre år, og at en sådan belejring medfører hungersnød og død, især blandt børn, er åbenlyst. At se sine børn dø som resultatet af en guddommelig beslutning er derfor ganske kendt blandt dem, der gennemlevede det babyloniske herredømme, hvad enten de var i eksil eller forblev i Juda. Som Tod Linafelt formulerer det: "The content of the book itself calls attention to issues of survival in the face of destruction, as the survival of her children becomes an overriding concern of personified Zion" (Linafelt 2000, 20). Derfor giver det også god mening at se 1 Mos 22 som en fortælling om netop deres møde med Gud. Også for eksiltidens fortælling om Abraham handler det om meningsløse tab af børn, som skulle have været begyndelsen på en slægt og et folk, så talrigt som himlens stjerner og havets sand.

Bag ved persertidens heroiske billede af den retfærdige Abraham ligger således en virkelighed, hvor forældre har oplevet, at deres tillid til en nådig og barmhjertig Gud blev sat på en hård prøve. Den Gud, som det almindelige menneske kendte, den personlige skytsgud, der tog sig af dem, der stolede på ham - vi kender denne religionstype fra de gammeltestamentlige tillidssalmer som Sl 23; 30; 127 og 128 - 
viste sig at tillade fjenderne at ødelægge byen, templet og landet. Det spørgsmål måtte derfor rejse sig, om man kunne stole på denne Gud? Mange tekster i Det Gamle Testamente peger på, at der bag dem står traumatiserede fortællere og tilhørere, der gennemlevede deres traumer ved at stille Gud til ansvar. Det er, hvad der sker i Klagesangene, hvor Zion appellerer til de forbipasserende om dog at se hendes smerte, når Gud ikke vil: ${ }^{37}$

\section{Rører det jer ikke, alle I, der går forbi?}

Se jer omkring, om der findes en smerte som den, der ramte mig, da Herren kuede mig på sin glødende vredes dag

(Klages 1,12).

Efter en sidste appel til Gud om at huske, hvad der er sket med Zion, slutter Klagesangene med en forsigtig bøn om, at han vil tage sit udmattede og skyldbetyngede folk til sig:

Hvorfor glemmer du os for evigt? Hvorfor svigter du os for altid?

Lad os vende om til dig, Herre, så vi vender om,

gør vore dage nye, som de var i fortiden,

hvis du ikke helt har forkastet os

og ikke er alt for vred på os.

(Klages 5,20-22).

Den klagende kalder på den stærke Gud, der kan hjælpe, hvis han vil; men hun er ikke sikker på, at det vil ske.

Så vidt går 1 Mos 22 ikke. Til den, der har måttet ofre det allermest dyrebare siger teksten: "Ja, Gud satte dig på prøve, men han vil også gribe ind. Du har mistet, men der er håb forude." Abrahams Gud er, i modsætning til Gud i Klagesangene, den, der ser (1 Mos 22,14). Abraham giver bjerget navnet "Jahve ser" (יהוָה ירְֶֶ:), et navn der understreges af fortællerens omtolkning: "Bjerget, hvor Jahve viser sig"

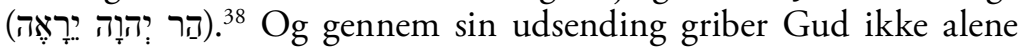
ind ved at udpege et erstatningsoffer (1 Mos 22,13), men også ved at

37. Jf. “Se dog, Jahve, jeg er i nød”, Klages 1,20. Linafelt peger på nødvendigheden for den traumatiserede $i$, at hendes smerte og lidelse bliver set, for at hun kan komme videre; han identificerer imperativerne til Jahve om at se som "a strong move away from the death represented by the genre of the funeral song and toward the drive for live represented by the genre of lament. The move, however, is not easy or automatic, but proceeds through the survivor's acute experience of suffering. Such suffering must be "seen", in the words of Zion" (Linafelt 2000, 44).

38. Man kunne overveje, om der er en lydlig, folkeetymologisk (skønt ikke filolo-

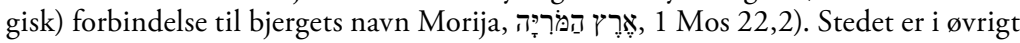
ukendt, men forbindes - interessant nok i forlængelse af den teologiske affinitet til 
afgive et højtideligt løfte om afkom "så talrige som himlens stjerner og som sandet ved havets bred" (1 Mos 22,17).$^{39}$ Dette løfte forbindes direkte med villigheden til at ofre den eneste søn.

Hvor villig den Abraham egentlig var, som mistede alt under de babyloniske hæres belejringer og plyndringer, er nok tvivlsomt, men offeret er under alle omstændigheder sket. 1 Mos 22 giver derfor ny identitet til den, som Gud har berøvet alt, og siger: "Du har ofret, men Gud ser dig igen”. Det var den mening, der kunne skabes i meningsløsheden. En mening, der ikke talte om skyld, som det ellers ofte er tilfældet i de gammeltestamentlige tekster, ${ }^{40}$ men om opofrelse, som ikke talte om straf, men om at Gud vender sig bort fra sin oprindelige plan og griber ind midt i sit eget vanvid.

Det er måske den Gud, vi skal lede efter i Det Gamle Testamente, ikke almagtens og alvidenhedens strenge Gud, men den Gud, der ser midt i det uudholdelige. Måske er det slet ikke så meget Abraham, der skal være forbillede for mennesker, som det er hans Gud, der skal lære af sig selv, at han er "nådig og barmhjertig, sen til vrede og rig på tilgivelse". Og så er det måske slet ikke nødvendigt at "tage afsked med Abraham", som Nørager anbefaler.

\section{Afsluttende bemærkninger}

Læsningen af 1 Mos 22 viser i hvor høj grad kontekst og forståelse hører sammen. Læseren stiller sine spørgsmål, og alt efter sin personlige og sociologiske kontekst finder han eller hun sit svar. Det er altså på en måde ikke teksten, der har en Sitz-im-Leben, men læseren. Tages der udgangspunkt i læserens kontekst som forståelsesramme, mister selve teksten sin iboende autoritet og kravet om én absolut sandhed, idet sandheden i teksten bliver afhængig af den situation, hvori den læses. Det er således ikke længere teksten, der interpreterer sig selv,

\footnotetext{
Klagesangene - et enkelt sted med tempelbjerget i Jerusalem, nemlig det fra persertiden stammende 2 Krøn 3,1.

39. Vedrørende Klagesangene påpeger Linafelt, at "Since the children of Zion are poetic representations of the inhabitants of the city of Jerusalem, this concern for the survival of children reflects as well a larger concern for the survival of the Jewish people" (Linafelt 2000, 20).

40. Til Det Gamle Testamente som traumalitteratur se Becker m.fl. 2014, heri særligt Else K. Holt, "Daughter Zion: Trauma, Cultural Memory and Gender in OT Poetics" (162-76), Louis Stulman: "Reading the Bible through the Lens of Trauma and Art" (177-92), Kathleen M. O'Connor, "How Trauma Studies Can Contribute to Old Testament Studies" (210-22), Daniel L. Smith-Christopher, "Trauma and Old Testament: Some Problems and Prospects" (223-43).
} 
men den kontekstualiserede læser, der stiller sine spørgsmål. Dette er ikke bare en post-moderne laissez-faire attitude, men derimod en kritisk tilgang, der tager historien alvorligt. Hvad der var sandt for den persiske enklavemenighed var ikke nødvendigvis det samme som for deres forgængere i det babyloniske eksil. Det ser vi i 1 Mos 22 ikke gennem analyse af tekstens redaktionelle udvikling, ${ }^{41}$ men ved at tage udgangspunkt i et spørgsmål om, hvilke problemer, der var relevante for læsere og modtagere i en bestemt historisk periode.

En sådan kontekstuel læsestrategi kan også anvendes i forhold til de senere fortolkninger af 1 Mos 22. Spørgsmålet bliver da, om Kierkegaards læser, Johannes de silentio, med sin kamp for at beskrive og forstå individets radikale hengivelse i lydighed, deler problemer med en nutidig læser? For mig at se er den nutidige spørgeramme snarere en opmærksomhed på en moderne Abraham, der mister alt af urimelige grunde og skal finde vej gennem denne urimelighed til en genopbyggelse af sit liv.

Så der er ingen grund til at forlade Abraham, kun til teologisk at erkende og videreformidle, at han som forbillede ikke nødvendigvis peger på et krav om teleologisk at suspendere det etiske, men derimod på Guds løfter om at se og gribe ind, selv i den ultimative prøvelse.

41. Kapitlet er ifølge Claus Westermann en sammenhængende narrativ enhed, bortset fra v. 15-18, der ikke har nogen funktion (Westermann 1981, 434). Min uenighed i denne udskillelse af versene fremgår af den ovenstående analyse. 